\title{
Influence of Rice Compost Fortified with Bioagents on Guar Root-Rot Disease
}

\author{
Abd-El-Rahman, S.S. ${ }^{1}$; Khalil, A.A. ${ }^{1}$ and \\ Balabel, N.M. ${ }^{1 \& 2}$
}

1- Plant Pathology Research Institute, Agricultural Research Center, Giza, Egypt.

2- Potato Brown Rot Project, Dokki, Giza, Egypt

\begin{abstract}
Compost was used as soil treatment either single or mixed with CTichoderma harzianum, Pseudomonas flourescens and Glomus sp. to study their efficiency against guar (Cyamopsis tetragonoloba) root rot caused by Sclerotium rolfsii. In vitro, among different bacteria isolated from compost wash, two isolates showed strong inhibitory effect against mycelial growth of $S$. rolfsii and were identified as Bacillus subtilis and $B$ amyloliquefaciens using Genetic analyzer (Applied Biosystem, Hitachi 3500).In the present work, mixed compost and bioagents was used to decrease disease incidence of root rot in guar plants. In pot experiments, soil amended with compost alone or mixed with bioagents provided a good protection against root rot. Soil amended with compost mixed with $T$. harzianum or $P$. fluorescens were superior that produced $82.35 \%$ and $76.48 \%$ decrease, respectively. Microbial population in the plant rhizosphere increased significantly as a result of application of compost alone or mixed with bioagents. Negative correlation was found between disease incidence and microbial population in the rhizosphere. Also, Soil amended with compost alone or mixed with bioagents increased plant nutrient uptake and improved soil fertility (NPK). Marked decrease in sclerotia germination of the pathogen in the soil amended with compost alone or mixed with bioagents was recorded. Soil amended with compost mixed with T.harzianum or $P$. fluorescens completely inhibited sclerotia germination. The aforementioned treatment not only decreased disease incidence but also increased fresh and dry weights of the plant as well as number of nodules compared to untreated control. Pilot field experiments are required.
\end{abstract}

Keywords: Guar, Trichoderma harzianum, Pseudomonas fluorescens, Glomus sp, rhizosphere, Sclerotium rolfsii, germination of sclerotia, macro-elements, rice straw compost and fortified compost.

Guar (Cyamopsis tetragonoloba L. Taub) is a multipurpose legume crop that is being cultivated for feed, summer green fodder, green manuring and other purposes (Arora and Pahuja, 2008). Also, guar gum is used in various industries and pharmaceutical purposes (Kalpana et al., 2009). 
The crop is subjected to attack by different soil-borne pathogens (Fusarium spp., Sclerotium rolfsii, Macrophomina phaseolina and Rhizoctonia solani) which cause considerable yield losses (Omar et al., 1994; Lodha et al., 2010 and Bareja et al., 2013). Sclerotium rolfsii, the causal of guar root rot disease has an extensive host range and produce sclerotia which play an outstanding role in the survival of the pathogen in the soil (Punja, 1985). So, using crop rotation to control the pathogen is not effective. Furthermore, application of fungicides to control soil-borne diseases causes hazards to human health and increase environmental pollution.

Several disease control methods have been applied showing a reasonable control of $S$. rolfsii such as saponine (Abdel-Rahman et al., 2018). Composts have been widely explored as an eco-friendly option for controlling soil-borne diseases (Joshi et al., 2009), and different investigations used compost alone or combined with $T$. harzianum, Pseudomonas spp ., Bacillus spp., or mycrorrhiza to control soil-borne diseases (Singh et al. 2012; Abd El-Ati and El-Hadidy, 2013; El-Mohamedy et al., 2013; and Shahiduzzaman, 2015). The suppressive effect of compost is due to the biotic factor including the inhibitory microbes (bioagents) which might be partly responsible for the efficacy of compost in decreasing soil-borne diseases (Naware, 2008).

Application of composts as soil treatments usually expressed as a significant effect on the population of fungi, bacteria and actinomycetes in the plant rhizosphere (Lodha et al., 2010; Bareja et al., 2013 and Bonilla et al., 2015). Negative correlation was found between disease incidence and microbial population in the rhizosphere (Yanli et al., 2012).

Improving soil fertility (Bareja et al., 2013 and Singh et al., 2013) and increase nutrients uptake by plant is additional benefit effects of compost through increasing nutrient availability (Zaghloul et al., 2010). This increase will be reflected in improving plant growth (Salem et al., 2012 and Borrega-Benjumea et al., 2014). Also, application of compost alone or combined with bioagents as soil treatment reduce germination of the pathogen propagules specially sclerotia which resulted in significant decrease in disease incidence (Bulluck and Ristaino, 2002; Aujla et al., 2004 and Xiaojia et al., 2010).

The objectives of this investigation are to study: 1- The effect of soil amended with compost alone or combined with bioagents against root rot disease caused by $S$. rolfsii. 2- Effect on rhizosphere population. 3- Effect on nutrients uptake by plants and soil fertility. 4- Effect on survival of sclerotia in the amended soil. 5- Effect on plant growth and nodulation. 6- Evaluate the efficiency of some bacteria isolated from compost extract on mycelial growth of $S$. rolfsii.

Egypt. J. Phytopathol., Vol. 46, No. 2 (2018) 


\section{Materials and Methods}

The experiment was carried out in season 2016 in the greenhouse of Seed Pathol. Res. Dept., (SPRD), Plant Pathol. Res, Inst. (PPRI), Agri. Res. Cent. (ARC), Giza, Egypt.

Compost used:

Rice straw compost (RS compost) obtained from Soil, Water and Enviro. Res. Inst. (SWERI), ARC, was used in this investigation. The main properties of the compost are shown in Table (1).

\section{Table (1): Properties of rice straw compost used in the present study}

\begin{tabular}{|l|c|}
\hline \multicolumn{1}{|c|}{ Property } & Value \\
\hline PH & 7.85 \\
\hline E.C. $(\mathrm{ds} / \mathrm{m})$. & 2.43 \\
\hline Organic matter $(\%)$ & 25.2 \\
\hline Total N (\%) & 1.53 \\
\hline Total P (\%) & 0.59 \\
\hline Total K (\%) & 0.93 \\
\hline C/N ratio & 15.63 \\
\hline Total soluble N (ppm) & 298 \\
\hline Available P $(\mathrm{ppm})$ & 150.6 \\
\hline Available K $(\mathrm{ppm})$ & 483 \\
\hline
\end{tabular}

Source of Sclerotium rolfsii:

Two pathogenic isolates of Sclerotium rolfsii previously isolated from guar samples from Damiette and Giza governorates respectively, were obtained from Legumes Dis. Res. Dept, PPRI, ARC, Giza and examined for pathogenic potentials.

Source of the bioagents:

1. Pseudomonas fluorescens and Glomus sp. (2000 spore/g soil) were obtained from

Dept. of Microbiol., Soil, Water and Environ. Res. Inst., ARC, Giza.

2. Trichoderma harzianum was obtained from Dept. Legumes Dis., Plant Pathol. Res. Inst., ARC, Giza.

Preparation of $P$. fluorescens inoculum:

$P$. fluorescens was cultured in nutrient broth medium in $250 \mathrm{ml}$ capacity flasks, each containing $100 \mathrm{ml}$ medium. The flasks were incubated at $\pm 28^{\circ} \mathrm{C}$ for $24 \mathrm{~h}$., and contents were adjusted to provide $10^{8} \mathrm{cfu} / \mathrm{ml}$.

Preparation of T. harzianum inoculum:

Plates containing Potato Dextrose Agar (PDA) medium were inoculated with discs ( $5 \mathrm{~mm}$ diam.) of 5 days-old culture of $T$. harzianum. The plates were incubated at $30 \pm 1{ }^{\circ} \mathrm{C}$ for 7 days, and spore suspension was adjusted to give approximately $3 \times 10^{6}$ spore/ml using haemocytometer. 
Effect of soil amended with either single compost or mixed with bioagents on guar root rot caused by $S$. rolfsii:

a. Preparation of pathogen inoculum:

Bottles (500 ml in volume) containing Corn meal-Sand medium $(3: 1 \mathrm{w} / \mathrm{w})$ were sterilized and inoculated with discs $(5 \mathrm{~mm})$ of six days old culture of $S$. rolfsii . Incubation at $30 \pm 1^{\circ} \mathrm{C}$ for 21 days was made.

\section{b. Soil infestation:}

Soil infestation with the pathogen was carried out by mixing fungal culture with sterilized potted-soil at the rate of $2.5 \%(\mathrm{w} / \mathrm{w})$. The infested soil was watered for 7 days to enhance growth and distribution of the fungal inoculum.

Compost was added to the infested soil before sowing at the rate of $5 \%(\mathrm{w} / \mathrm{w})$ followed by the tested bioagents for each pot $(35 \mathrm{~cm}$ diameter). The treatments were:

1 Pots containing infested soil and compost alone.

2 Pots containing infested soil, compost and $10 \mathrm{ml}$ cell suspension of $P$. fluorescens $\left(10^{8} \mathrm{cfu} / \mathrm{ml}\right)$.

3 Pots containing infested soil, compost and $10 \mathrm{ml}$ spore suspension of $T$. harzianum $\left(3 \times 10^{6}\right)$.

4 Pots containing infested soil, compost and $15 \mathrm{~g}$ of mycorrhiza (200 spore/g soil).

5 Pots containing infested soil only, and then sown with guar seeds treated with fungicide (Rizolex-T) at the rate of $3 \mathrm{~g} / \mathrm{kg}$ seeds used as comparison treatment.

6 Pots containing infested soil only without any treatment as control.

All pots were sown with guar seeds (Local cv.). Then rhizobia were added to the soil at the rate of $3 \mathrm{~g} /$ pot. Three replicates were used for each treatment and eight seeds per pot were sown. The growing plants were examined periodically and disease incidence was recorded 60 days after sowing. Also, fresh and dry weight of guar plants (root and shoot), as well as number of nodules per plant were recorded 75 days after sowing.

Effect of soil amended with either single compost or mixed with bioagents on sclerotial germination of $S$. rolfsii in the soil:

Plates of PDA medium were inoculated with discs (5 $\mathrm{mm}$ in diameter) of $S$. rolfsii obtained from the periphery of six-day-old culture. Incubation at $25^{\circ} \mathrm{C}$ for 21 days to form maximum number of sclerotia was made. The sclerotia were collected and surface sterilized by soaking in $3 \%$ sodium hypochlorite. The sterilized sclerotia were gathered in nylon mesh bags, 30 sclerotia/ bag, and deeply buried at $2 \mathrm{~cm}$ in soil containing the following treatments:

Egypt. J. Phytopathol., Vol. 46, No. 2 (2018) 
1 Pots containing sterilized soil and compost.

2 Pots containing sterilized soil, compost and $10 \mathrm{ml}$ cell suspension of $P$. fluorescens $\left(10^{8} \mathrm{cfu}\right)$.

3 Pots containing sterilized soil, compost and $10 \mathrm{ml}$ of spore suspension of $T$. harzianum ( $3 \times 10^{6}$ spore $\left./ \mathrm{ml}\right)$.

4 Pots containing sterilized soil, compost and $15 \mathrm{~g}$ of mycorrhiza (200 spore/g soil).

5 Pots containing sterilized soil only used as control treatment.

Compost was added to the infested soil at the rate of $5 \%(\mathrm{w} / \mathrm{w})$. The aforementioned pots were irrigated periodically for three times at 20 days intervals. Three pots were used for each treatment. The buried sclerotia recovered periodically after 15, 30 and 60 days, washed and sterilized as mentioned before, then placed in plates containing (PDA) medium. The plates were incubated at $25^{\circ} \mathrm{C}$ for 4 days. The survival of sclerotia was recorded as the percentage of germinating sclerotia.

Isolation of bacteria from compost water wash:

Two grams of the compost were transferred into flask $100 \mathrm{ml}$ capacity containing $20 \mathrm{ml}$ of sterilized distilled water and was shaken using shaker for $1 \mathrm{~h}$. After resting the liquid was serially diluted to $\left(10^{-6}\right)$. Plates containing Potato Dextrose Agar (PDA) medium were inoculated with $1 \mathrm{ml}$ of the diluted compost wash, then incubated at $28 \pm^{\circ} \mathrm{C}$ for 5 days. Apparently different isolates of bacteria were selected, purified and examined for antagonistic effect against two isolates of S. rolfsii as follows:

Plates containing (PDA) medium were inoculated at one side with a disc $(5 \mathrm{~mm}$ diam) of $S$. rolfsii from the periphery of 5 days-old culture. The bacterial isolates individually was streaked on the opposite side. Control plates of (PDA) medium were inoculated with a disc of $S$. rolfsii only. Three replicates were used for each isolate. Three replicates were used for each treatment. All plates were incubated at $28 \pm{ }^{\circ} \mathrm{C}$. When the mycelial growth covered the whole surfaces in the control, the plates were then examined and inhibition distance was determined. Isolates of bacteria reflected strong antagonist were selected and identified using Genetic analyzer (Applied Biosystem, Hitachi 3500).

\section{Identification of antagonistic bacteria:}

One colony of the tested isolates was suspended in $100 \mu \mathrm{l}$ of lysis solution $(0.05$ $\mathrm{m} \mathrm{NaOH}, 0.25 \%$ sodium dodecyl sulphate [SDS]) and was incubated for $15 \mathrm{~min}$ at $100^{\circ} \mathrm{C}$. The suspension was centrifuged for $1 \mathrm{~min}$ at $13,800 \mathrm{~g}$ and diluted 20 -fold in DNA-free distilled water (pellet discarded). One micro liter of the diluted suspension was used in each reaction. The V6 to V8 region of the 16S rRNA gene was amplified from the extracted DNA using the primers $968 \mathrm{f}$ and $1401 \mathrm{r}$ as described in Hiddink et al. (2005). Table (2) shows the characteristics of primers used in this investigation. The amplified PCR products were purified using Pure Link TM quick gel extraction kit (Invitrogen, Life Technologies, Löhne, Germany).

Egypt. J. Phytopathol., Vol. 46, No. 2 (2018) 
Twenty ng from each purified PCR product were added to $20 \mu$ PCR and amplified according to the diagnostic procedure by ABI Prism ${ }^{\circledR}$ BigDye ${ }^{\circledR}$ Terminator V3.1 Cycle Sequencing Kits (Applied Biosystems, Foster City, CA, USA). The sequencing process was conducted at the Potato Brown Rot Project laboratories (PBRP),(Dokki, Egypt) using an 8 capillary Genetic Analyzer (Applied Biosystem). The partial 16S rRNA gene sequences (containing a sequence between U968-f and U1401-r) were compared with the sequences of the Gen Bank DNA database by using the BLASTN algorithm (http://blast.ncbi.nlm.nih.gov/Blast.cgi), and nucleotide blast was selected. Bioedit software was used to refine forward and reverse DNA sequences.

Table 2. Characteristics of primers used for DNA/RNA sequencing

\begin{tabular}{|c|c|c|c|}
\hline PCR target & $\begin{array}{c}\text { Primer } \\
\text { name }\end{array}$ & Sequence 5'-3' & $\begin{array}{c}\text { Primer } \\
\text { position }\end{array}$ \\
\hline Bacterial 16s & U968-f & 5'-AACGCGAAGAACCTTAC-3' & 16 S-968* \\
\hline Bacterial 16s & L1401-r & 5'-CGGTGTGTACAAGACCC-3' $^{*}$ & $16 \mathrm{~S}-1401^{* *}$ \\
\hline
\end{tabular}

* Felske et al., (1996) and ** Heuer and Smalla (1997).

Effect of soil amended with either single compost or mixed with bioagents on total microbial flora in the rhizosphere of guar plants:

Guar plants in each treatment were uprooted carefully with intact root system 20 days after sowing. Ten grams of rhizosphere soil of each treatment were transferred into a flask containing $90 \mathrm{ml}$ sterile water and shaken for 15 minutes. This gave a dilution of $10^{-1}$ concentration and serial dilutions of soil suspension were conducted up to $10^{-6}$ using sterilized water.

Total count of actinomycetes was estimated at the dilution of $10^{-3}$ on Jensen's medium (Allen, 1953).

Total count of fungi was estimated at the dilution of $10^{-4}$ on Martin's medium (Martin, 1950).

Total count of bacteria was estimated at the dilution of $10^{-6}$ on soil extract yeast agar medium (Skinner et al., 1952).

Three plates from each dilution were used. All plates were incubated at $28^{\circ} \mathrm{C}$. The total fungi were counted after 5 days; the total bacteria were counted after 4 days and the total actinomycetes after 7 days.

Effect of plant treatments on macro-elements content along with soil fertility (NPK):

Nitrogen, phosphorus and potassium contents in guar plants and in the treated soils were estimated in Laboratories of Soil, Water and Environment Res. Inst., ARC.

a. Plant shoot analysis:

Shoot samples of guar plants from each treatment were collected 75 days after sowing and oven dried at $70^{\circ} \mathrm{C}$. Nitrogen content was determined according to the Egypt. J. Phytopathol., Vol. 46, No. 2 (2018) 
method described by Piper (1950). Phosphorus and potassium were determined according to the method described by Page et al. (1982), on chemical basics.

\section{b. Soil analysis:}

Soil samples were collected from each treatment at the end of the experiment. Available soil nitrogen was automated determined according to the method described by Markus et al. (1982). Available phosphorus was determined according to the method described by Olsen et al. (1954). Potassium was determined according to Jakson (1967).

\section{Statistical analysis:}

Analysis of variance (ANOVA) of the obtained data, correlation, and regression were performed with the software package SPSS. The least significant difference (LSD) was used to compare treatment means (Gomez and Gomez, 1984).

\section{Results}

Effect of soil amended with either single compost or mixed with bioagents on guar root rot caused by $S$. rolfsii:

Table (3) shows that the tested treatments significantly decreased root rot caused by $S$. rolfsii, and the fungicide treatment recorded the lowest disease incidence. However, soil amended with compost only or mixed with bioagents effectively provided a good protection (52.94-82.35\% decrease in disease incidence). Compost mixed with T. harzianum was superior in this regard (82.35\% reduction), followed by compost mixed with $P$. fluorescens then compost mixed with Glomus sp., respectively. While compost alone showed the lowest effect.

Table 3: Effect of soil amended with either single compost or mixed with bioagents on guar root rot caused by $S$. rolfsii

\begin{tabular}{|c|c|c|}
\hline Treatment & Disease incidence (\%) & Decrease (\%) \\
\hline Compost & 26.67 & 52.94 \\
\hline Compost + P. fluorescens & 13.33 & 76.48 \\
\hline Compost + T. harzianum & 10.00 & 82.35 \\
\hline Compost + Glomus sp. & 23.33 & 58.83 \\
\hline Rhizolex-T & 6.67 & 88.23 \\
\hline Control & 56.67 & -- \\
\hline L.S.D. (P $\leq 0.05)$ & 15.06 & \\
\hline
\end{tabular}

Effect of soil amended with either compost alone or mixed with bioagents on sclerotial germination of $S$. rolfsii in the soil:

Data in Table (4) show that soil amended with compost alone or mixed with bioagents significantly decreased sclerotia germination in the soil during examination period compared to untreated control and the decrease was increased by time. Among the tested treatments, compost mixed with $T$. harzianum or $P$. fluorescens completely inhibited sclerotial germination during 30 days (100\% 
inhibition in germination). On the other side, single compost or compost mixed with Glomus sp. were less effective.

Table 4: Effect of soil amendment with either single compost or mixed with bioagents on sclerotia germination of $S$. rolfsii in the soil

\begin{tabular}{|l|c|c|c|}
\hline \multirow{2}{*}{\multicolumn{1}{|c|}{ Treatment }} & \multicolumn{3}{|c|}{ Sclerotia germination (\%) after (days) } \\
\cline { 2 - 4 } & 15 & 30 & 60 \\
\hline Compost & 60.00 & 51.11 & 46.67 \\
\hline Compost + P. fluorescens & 14.45 & 0.00 & 0.00 \\
\hline Compost + T. harzianum & 6.67 & 0.00 & 0.00 \\
\hline Compost + Glomus sp. & 54.44 & 48.89 & 43.33 \\
\hline Control & 100 & 100 & 100 \\
\hline L.S.D. $(\mathrm{P} \leq 0.05)$ & 12.03 & 5.20 & 7.18 \\
\hline
\end{tabular}

Isolation of bacteria from compost water wash:

Data presented in Table (5) show that the tested bacteria from the rice straw compost differed in their inhibition of the mycelial growth of $S$. rolfsii. Bacterial isolates number 5 and 11 were the most effective ones. They recorded maximum inhibition zones. Fig.(1) shows the antagonistic isolates belonged to the genusBacillus and identified as B. subtilis and B. amyloliquefaciens, respectively using Genetic Analyzer (Applied Biosystem, Hitachi 3500).

Table 5: Antifungal effect of different bacteria isolated from compost against two isolates of $S$. rolfsii in vitro

\begin{tabular}{|c|c|c|}
\hline \multirow{2}{*}{$\begin{array}{c}\text { Bacterial } \\
\text { isolate No. }\end{array}$} & \multicolumn{2}{|c|}{ Inhibition zone (cm) } \\
\cline { 2 - 3 } & S. rolfsii $(1)$ & S. rolfsii (2) \\
\hline 1 & 0.0 & 0.0 \\
\hline 2 & 0.0 & 0.0 \\
\hline 3 & 0.5 & 0.0 \\
\hline 4 & 0.0 & 0.3 \\
\hline 5 & 2.3 & 1.0 \\
\hline 6 & 0.0 & 0.0 \\
\hline 7 & 0.0 & 0.8 \\
\hline 8 & 0.0 & 0.0 \\
\hline 9 & 9.0 & 0.5 \\
\hline 10 & 1.8 & 0.0 \\
\hline 11 & 0.0 & 1.1 \\
\hline 12 & 0.0 & 0.3 \\
\hline 13 & 0.0 & 0.0 \\
\hline 14 & 0.0 & 0.0 \\
\hline 15 & 0.7 & 0.0 \\
\hline 16 & 0.0 & 0.0 \\
\hline 18 & 0.0 & 0.0 \\
\hline 18 & 0.5 & 0.0 \\
\hline 19 & 0.0 & 0.0 \\
\hline
\end{tabular}

Egypt. J. Phytopathol., Vol. 46, No. 2 (2018) 
Isolate No.5.

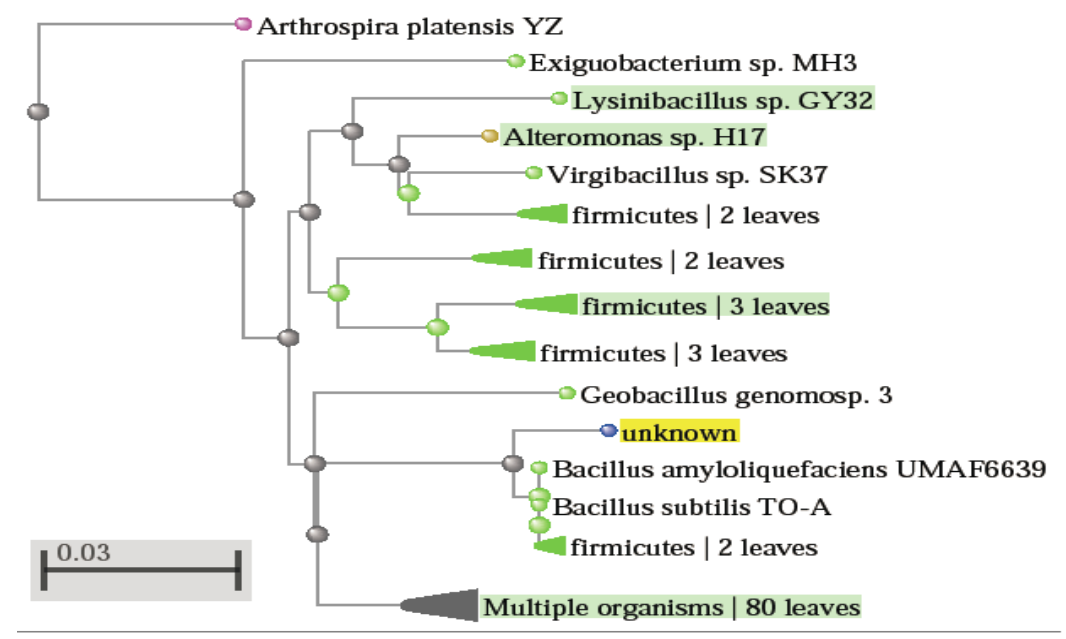

Isolate No.11.

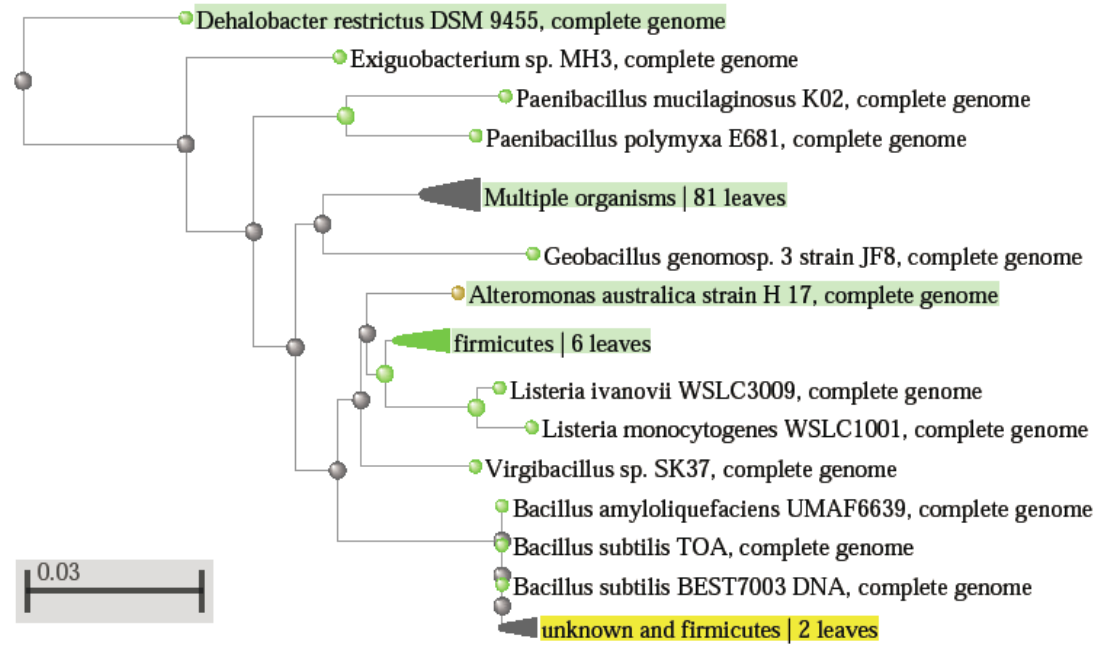

Fig.1: Distance tree using Neighbor Joining Blast Tree using rRNA type strains / prokaryotic_16S_ribosomal_RNA database. Unknown refers to the antagonistic bacteria (5 and 11) isolated from compost. 
Effect of soil amended with either single compost or mixed with bioagents on total microbial flora in the rhizosphere of guar plants:

Data presented in Table (6.a) show that application of compost alone or mixed with bioagents significantly increased microbial population in rhizosphere compared to fungicide treatment. The treatments have shown a marked influence on total number and types of rhizosphere microorganisms. Compost mixed with $T$. harzianum or Glomus sp. recorded the highest population of actinomycetes. While, compost mixed with $T$. harzianum followed by compost combined with $P$. fluorescens recorded the maximum number of fungi in the rhizosphere. Population of bacteria in the rhizosphere showed peak increase when the soil was amended with compost mixed with $P$. fluorescens, followed by compost mixed with $T$. harzianum.

Table 6.a: Effect of soil amended with either single compost or mixed with bioagents on total microbial population in rhizosphere of guar seedlings

\begin{tabular}{|l|c|c|c|}
\hline \multirow{2}{*}{\multicolumn{1}{|c|}{ Treatment }} & \multicolumn{3}{c|}{ Colony forming unit/g rhizosphere } \\
\cline { 2 - 4 } & Actino. $\times 10^{3}$ & Fungi $\times 10^{4}$ & Bacteria $\times 10^{6}$ \\
\hline Compost & 25.00 & 97.33 & 164.00 \\
\hline Compost + P. fluorescens & 26.67 & 158.67 & 374.67 \\
\hline Compost + T. harzianum & 45.00 & 296.00 & 300.00 \\
\hline Compost + Glomus sp. & 37.67 & 153.33 & 182.33 \\
\hline Fungicide (Rizolex-T) & 7.67 & 58.33 & 101.33 \\
\hline Control & 10.33 & 84.00 & 77.33 \\
\hline L.S.D. (P $\leq 0.05)$ & 9.13 & 11.11 & 13.00 \\
\hline
\end{tabular}

Data presented in Table (6.b) indicate negative correlations between root rot incidence and number of actinomycetes and fungi in the rhizosphere, and the correlations between root rot disease incidence and number of bacteria in the rhizosphere was significantly negative as well.

Table 6.b. Correlation between guar root rot (GRR) disease incidence and number of actinomycetes, fungi and bacteria in the rhizosphere

\begin{tabular}{|c|c|c|c|}
\hline \multirow{2}{*}{ Treatment } & \multicolumn{3}{|c|}{ Colony forming unit/g soil rhizosphere } \\
& Actinomycetes & Fungi & Bacteria \\
\hline \multirow{2}{*}{ Incidence $(\mathrm{GRR})$} & $-0.357^{\mathrm{a}}$ & -0.351 & $-0.505^{*}$ \\
& $(\mathrm{P}=0.145)$ & $(\mathrm{P}=0.153)$ & $(\mathrm{P}=0.033)$ \\
\hline
\end{tabular}

$\mathrm{a}=$ linear correlation coefficient $(\mathrm{r}), *$ significant.

Effect of plant treatments on macro-elements content and soil fertility (NPK):

Data presented in Table (7) show that the tested treatments significantly increased macro-elements in guar plants compared to untreated control. Compost mixed with bioagents was more effective than compost alone, indicating by the

Egypt. J. Phytopathol., Vol. 46, No. 2 (2018) 
maximum increase in macronutrients content $(\mathrm{N}, \mathrm{P}$ and $\mathrm{K})$. Whereas, fungicide treatment was the least effective one.

Table 7: Effect of soil amendment with either single compost or mixed with bioagents on macro-elements content in guar plants

\begin{tabular}{|l|c|c|c|}
\hline \multirow{2}{*}{\multicolumn{1}{|c|}{ Treatments }} & \multicolumn{3}{c|}{ Macro-elements (\%) } \\
\cline { 2 - 4 } & $\mathrm{N}$ & $\mathrm{P}$ & $\mathrm{K}$ \\
\hline Compost & 3.12 & 0.15 & 2.72 \\
\hline Compost + P. fluorescens & 3.50 & 0.15 & 2.75 \\
\hline Compost + T. harzianum & 3.65 & 0.18 & 2.88 \\
\hline Compost + Glomus sp. & 4.12 & 0.16 & 2.82 \\
\hline Rizolex-T & 3.05 & 0.12 & 2.40 \\
\hline Control & 2.44 & 0.08 & 1.69 \\
\hline L.S.D. $(\mathrm{P} \leq 0.05)$ & 0.32 & 0.05 & 0.38 \\
\hline
\end{tabular}

Data presented in Table (8) show significant increase in soil fertility in soil amended with compost alone or mixed with bioagents. Also, compost mixed with bioagents was more effective than compost alone. Among the tested treatments, soil amended with compost mixed with $T$. harzianum or $P$. fluorescens recorded the maximum increase in soil NPK. Other treatments were less effective.

Table 8: Effect of soil amendment with either single compost or mixed with bioagents on soil fertility

\begin{tabular}{|l|c|c|c|}
\hline \multirow{2}{*}{\multicolumn{1}{|c|}{ Treatments }} & \multicolumn{3}{c|}{ Macro-elements (ppm) } \\
\cline { 2 - 4 } & $\mathrm{N}$ & $\mathrm{P}$ & $\mathrm{K}$ \\
\hline Compost & 29.67 & 33.00 & 345.00 \\
\hline Compost + P. fluorescens & 36.00 & 54.67 & 583.67 \\
\hline Compost + T. harzianum & 51.67 & 58.00 & 464.33 \\
\hline Compost + Glomus sp. & 44.00 & 40.67 & 359.33 \\
\hline Rizolex-T & 20.00 & 34.33 & 240.67 \\
\hline Control & 20.33 & 31.00 & 249.00 \\
\hline L.S.D. $(\mathrm{P} \leq 0.05)$ & 2.34 & 4.50 & 10.42 \\
\hline
\end{tabular}

Data presented in Table (9) show that the tested treatments significantly increased fresh and dry weights of guar plants. Maximum increase in fresh and dry weights was recorded when the soil was amended with compost mixed with $T$. harzianum or Glomus sp. Followed by compost mixed with P. fluorescens. Also, the number of nodules was significantly increased in all treatments. Compost mixed with $T$. harzianum followed by $P$. fluorescens and fungicide treatment recorded the maximum number of nodules, respectively. 
Table 9: Effect of soil amended with either single compost or mixed with bioagent on fresh and dry weight and number of nodules of guar plants

\begin{tabular}{|l|c|c|c|c|c|}
\hline \multirow{2}{*}{\multicolumn{1}{c|}{ Treatment }} & \multicolumn{2}{c|}{$\begin{array}{c}\text { Fresh weight } \\
\text { (g/plant) }\end{array}$} & \multicolumn{2}{c|}{$\begin{array}{c}\text { Dry weight } \\
\text { (g/plant) }\end{array}$} & $\begin{array}{c}\text { No. of } \\
\text { nodules/ } \\
\text { plant }\end{array}$ \\
\cline { 2 - 6 } & Root & Shoot & Root & Shoot & \\
\hline Compost & 5.49 & 32.85 & 1.94 & 8.45 & 17.00 \\
\hline Compost + P. fluorescens & 6.23 & 36.54 & 2.04 & 9.08 & 24.33 \\
\hline Compost + T. harzianum & 7.98 & 42.37 & 2.45 & 12.50 & 29.67 \\
\hline Compost + Glomus sp. & 7.71 & 37.72 & 2.06 & 11.72 & 19.67 \\
\hline Rizolex-T & 6.35 & 32.33 & 1.95 & 9.65 & 11.00 \\
\hline Control & 2.96 & 19.98 & 1.28 & 4.21 & 5.33 \\
\hline L.S.D. (P $\leq$ 0.05) & 2.08 & 8.42 & 0.56 & 2.06 & 8.54 \\
\hline
\end{tabular}

\section{Discussion}

In pot experiment, soil amended with compost alone or mixed with bioagents effectively decreased root rot disease incidence caused by $S$. rolfsii. Addition of bioagents improved disease suppressiveness of compost. Compost mixed with $T$. harzianum recorded the maximum decrease.

The suppressivness of compost is due to combination of biotic and abiotic factors. The biotic factor including the inhibiting microbes (bioagents) which partly responsible for the efficacy of compost in decreasing soil borne diseases (Naware, 2008) through decreasing the survival and multiplication of the pathogen in the soil by competition, antibiosis or direct parasitism of sclerotia (Elad et al., 2009). Abiotic factors, as related to some fungistatic compounds presented in compost (Dorias, 2011).

Different investigators used compost alone or mixed with bioagents to control soil-borne fungal diseases forming sclerotia. Bulluck and Ristaino (2002) found that soil amended with different types of compost fortified with $T$. harzianum significantly decreased southern blight disease of tomato caused by $S$. rolfsii. Trichoderma compost gave a good protection against lentil root rot disease caused by $S$. rolfsii (Shahiduzzaman, 2015). Also, Chilosi et al. (2017) found that green nursery compost fortified with $T$. harziaum markedly reduced root rot disease of ornamental plants caused by S. sclerotiorum.

In vitro, among different isolates of bacteria recovered from rice straw compost wash and tested against $S$. rolfsii, two isolates of genus Bacillus were found to be the most potent bacteria against $S$. rolfsii. They identified as $B$. subtilis and $B$. amyloliquefaciens. Testing these bacteria in vitro added evidence for specific forms of suppression (Rivera et al., 2004). Similarly, both Kavroulakis et al. (2010), Kerkeni et al. (2010) and Pane et al. (2012) who isolated bacteria from different Egypt. J. Phytopathol., Vol. 46, No. 2 (2018) 
types of compost, some of these bacteria showed antagonistic potential against soil borne diseases including $F$. oxysporum, Phytophthora cinnamon, F. solani, M. phaseolina, $R$. solani and Sclerotinia minor.

Soil amended with compost alone or mixed with bioagents resulted in subtle increase in microbial population in rhizosphere, especially when the compost was mixed with bioagents. Furthermore, negative correlation was found between microbial population and root rot incidence. Increasing rhizosphere population usually causes depletion in essential nutrients for survival and multiplication of the pathogen, thus preventing host infection, Chen et al. (1988).

The previous report studied the efficacy of some composts against soil-borne disease in relation to microbial population in the rhizosphere. In this respect, Joshi et al. (2009) observed obvious increase in total number of bacteria and fungi in plant rhizosphere as a result of application of urtic compost to control root rot disease of French bean caused by R. solani. Also, Lodha et al., (2010) and Bareja et al., (2013) indicated that application of compost to control M. phaseolina on different hosts was associated with a great increase in total number of fungi, bacteria and actinomycetes in plant rhizosphere. Bonilla et al. (2015) used different types of composts to control white root rot disease of avocado caused by Rosellina necatrix. They found a correlation between disease control and total number of bacteria in the soil and plant rhizosphere.

Application of compost alone or mixed with bioagents resulted in a pronounced increase in macro-elements content in guar plants. The increase was much higher when the soil was amended with compost mixed with bioagents. The increase in nutrients uptake may be dye to (1) compost enhanced the uptake of nutrients through stimulated microbial growth and favored root growth due to improvement in soil physical conditions (Kachot et al., 2001). (2) production of plant growth promoting substance by microorganisms which create favorable conditions for improving minerals uptake by plants (Morsy, 2005).

In the present work, obtained results were similar to those obtained by Zaghloul et al. (2010) who found higher increase in nutrients uptake in marjoram plants grown in soil amended with compost alone or mixed with T. harzianum compared to unamended control. Also Singh et al. (2013) noticed an increase in plant N, P and K uptake as a result of application of Pseudomonas monteili strain and Glomus fasciculatum under organic field conditions to control Fusarium wilt disease of Coleus forskohlii. Marked increase in soil fertility was found as a result of application of compost alone or mixed with bioagents. Soil amended with compost mixed with $T$. harzianum or $P$. fluorecences were superior in this regard. The increases in soil fertility as a result of application of compost and bioagents have been previously reported. Naware (2008) used rice straw compost fortified with $T$. harzianum to control damping-off disease caused by $R$. solani. He found that the 
decrease in disease incidence was associated with an improvement in soil fertility. Both Bareja et al. (2013) and Singh et al. (2013) indicated that application of compost alone or mixed with $T$. harzianum or $P$. monteilii to control M. phaseolina and $R$. solani resulted in marked increase in available N,P and $\mathrm{K}$ of the soil.

Generally, the increased soil fertility and macro-elements content in plants may be considered one of the beneficial effects of composts.

Under conditions of this investigation, noticeable decrease in sclerotia germination of $S$. rolfsii in soil amended with compost alone or mixed with bioagents was noticed untreated control.

Compost mixed with $T$. harzianum or $P$. fluorescens recorded $100 \%$ inhibtion in sclerotia germination during 30 days compared to other treatments. The decrease in sclerotia germination was correlated with the lowest disease incidence. The decrease in sclerotia germination may be due to the production of lytic enzymes by the bioagents which lyse sclerotia (Ojahian, 2011), or the production of viridiofungin A (VFA) and harzianic acid which suppress sclerotia germination (El-Hassan et al., 2009 and Vinale et al., 2009). Obtained results supported the previous work of Bulluck and Ristaino (2002), Aujla et al. (2004) and Xiaojia et al. (2010). They indicated that sclerotia germination of $S$. rolfsii and S. sclerotiorum was decreased to a great extent in soil amended with compost fortified with $T$. harzianum.

Compost alone or mixed with bioagents increased fresh and dry weight of guar plants. The increase in soil amended with compost mixed with bioagents was higher than other treatments. This increase may be due to the production of phytohormones by the bioagents and nutrients availability (Gravel et al. 2007). Also, the number of nodules per plant was significantly increased when compost was applied alone or mixed with bioagents. The increase was ranged between 2-5 folds compared to untreated control. The increase in number of nodules per plant due to the production of phytohormones by the bioagents which stimulate root growth, providing further infection rate and nodulation (Zhang et al., 2004). Obtained results are in agreement with those reported by Salem et al. (2012) and Borrego-Benjumea et al. (2014). They indicated that application of compost alone or mixed with bioagents to control soil borne disease usually associated with increase in plant growth. On the other side, Singh et al. (2008) and Singh et al. (2012) found that mixed application of compost and bioagents to control soil borne diseases resulted in obvious increase in number of nodules per plant compared to individual application or control treatment.

\section{References}

Abd-El-Ati, A.A and El- Hadidy, M.A. 2013. Improving productivity and control of soil borne diseases of broad bean by using different fertilization resources under reclaimed soil conditions, Egypt.. J. Agron., 35(2): 135-153.

Egypt. J. Phytopathol., Vol. 46, No. 2 (2018) 
Abdel-Rahman, S.S.; Omar, S.A. and Ali, A.A.M. 2018. Differentiation among Sclerotium rolfsii isolates in response to saponine treatment. Plant Pathol. and Quaran., 8(1):100-109.

Allen, O.N. 1953. Experiments in Soil Bacteriology. Burgess Publishing Co., Rev. ed., 2. USA.

Arora, R.N. and Pahuj, S.K. 2008. Mutagenesis in Guar (Cyamopsis tetragonoloba Taub.). Plant Mut. Rep., 2(1):7-9.

Aujla, I.S.; Sandhu, K.S.; Singh, P.P. and Handoro, F. 2004. The effect of soil amendments and treatment with Trichoderma spp. on survival of sclerotia of Sclerotinia sclerotiorum. J. Res. Punjab Agri. Univ., 39(4):521-527.

Bareja, M.; Mawar, R.; Mathur, M. and Lodha, S. 2013. On-farm waste- based composts in managing Macrophomina phaseolina induced dry root rot of guar in an arid environment. Aust. Plant Pathol., 42(1):9-16.

Bonilla, N.; Vida, C.; Alonso, M.M.; Landa, B.B.; Gaju, V.; Cazorla, F.M. and Vicente, A.de. 2015. Organic amendments to avocado crops induce suppressiveness and influence the composition and activity of microbial communities. Appl. and Environ. Microbiol., 81(10):3405-3418.

Borrego-Benjumea, A.; Basallote-Ureba, M.J.; Melero-Vara, J.M. and Abasi, P.A. 2014. Characterization of Fusarium isolates from asparagus field in southwestern Ontario and influence of soil amendments on fusarium crown and root rot. Phytopathology, 104(4):403-415.

Bulluck, L.R. and Ristaino, J.B. 2002. Effect of synthetic and organic soil fertility amendments on southern blight, soil microbial communities, and yield of processing tomatoes. Phytopathology, 92:181-189.

Chen, W.H.; Hoitink, H.A.J.; Schmitthenner, A.F. and Tuovinen, O.H. 1988. The role of microbial activity on the suppression of damping-off caused by Pythium ultimum. Phytopathology, 78:314-322.

Chilosi, G.; Aleandri, M.P.; Bruni, N.; Tomassini, A.; Torresi, V.; Muganu, M.; Paolocci, M.; Vettraina, A. and Vannini, A. 2017. Assessment of a suitability and suppressiveness of on-farm green compost as a substitute of peat in the production of lavender plants. Biocon. Sci. and Technol., 27(4):539-555.

Dorais, M. 2011. Suppressing soil-borne diseases of container growth plants using compost. Acta Hort., 893:169-181.

Elad, Y.; Maurhofer, M.; Keel, C.; Gessler, C. and Duffy, B. 2009. Biological control of Sclerotinia sclerotiorum on beans in field by Trichoderma asperellum and Clonostachys rosea. IOBC/WPRS Bulletin, 43:243-246. 
El-Hassan, A.; Walker, F.; Schone, J. and Buchenauer, H. 2009. Detection of viridio fungin A and other antifungal metabolites excreted by Trichoderma harzianum active against different plant pathogens. Eur. J. of Plant Pathol., 124(3): 457470.

El-Mohamedy, R.S.R,; Morsy, A.A. and Bakear, A.R.T. 2013. Utilization of biocomposted agricultural wastes in management of fusarium dry root rot disease on lime (Citrus aurantifolia L.). Inter. J. of Agric. Technol., 9(5): 12271239.

Felske, A.; Engelen, B.; Nübel, U. and Backhaus, H. 1996. Direct ribosome isolation from soil to extract bacterial rRNA for community analysis. Appl. and Environ. Microbiol., 62:4162-4167.

Gomez, K.A. and Gomez, A.A. 1984. Statistical Procedures for Agriculture Research. $2^{\text {nd }}$ Ed. John Wiley and Sons Ltd., New York, 680p.

Gravel, V.; Antoun, H. and Tweddell, R.J. 2007. Growth stimulation and fruit yield improvement of greenhouse tomato plants by inoculation with Pseudomonas putida or Trichoderma atroviride: Possible role of indole acetic acid (IAA). Soil Biol. and Biochem., 39(8):1968-1977.

Heuer, H., and Smalla, K. 1997. Application of denaturing gradient gel electrophoresis for studying soil microbial communities. In J. D. van Elsas, J. T. Trevors, \& E. M. H. Wellington (Eds.), Modern Soil Microbiol., 353-373. New York: Marcel Dekker Inc.

Hiddink, G.A.; Termorshuizen, A.J.; Raaijmakers, J.M. and van Bruggen, A.H.C. 2005. Effect of mixed and single crops on disease suppressiveness of soils. Phytopathology, 95:1325-1332.

Jakson, M.L. 1967. Soil Chemical Analysis. Prentic-Hall, Englewood Cliffs, New Jersey, USA.

Joshi, D.; Hooda, K.S.; Bhatt, J.C.; Mina, B.L. and Gupta, H.S. 2009. Suppressive effect of composts on soil-borne and foliar diseases of French bean in the field in the western India Himalayas. Crop Protec., 28(7): 608-615.

Kachot, N.A.; Malavia, D.D.; Solanki, R.M. and Sagarka, B.K. 2001. Integrated nutrient management in rainy-season groundnut (Arachis hypogaea). Indian J. of Agron., 46(3): 516-22.

Kalpana-Chauhan, G.S.; Chauhan, G.S. and Ahn, J.H. 2009. Synthesis and characterization of novel guar gum hydrogels and their use as $\mathrm{Cu}_{2}+$ sorbents. Biores. Technol., 100(14): 3599-3603.

Egypt. J. Phytopathol., Vol. 46, No. 2 (2018) 
Kavroulakis, N.; Ntougias, S.; Besi, M.T.; Kastou, D.A.; Ehaliots, C.; Zervakis, G.I. and Papado, K.K. 2010. Antagonistic bacteria of composted agro-industrial residue exhibit antibiosis against soil-borne fungal plant pathogens and protection of tomato plants from Fusarium oxysporum f.sp. radicis-lycopersici. Plant and Soil, 333(1/2): 233-247.

Kerkeni, A.; Ramadi, D.; Tarchoun, M., and Khedher, M. B. 2010. Effect of bacterial isolates obtained from animal manure compost extract on development of Fusarium oxysporum f.sp radices-lycopersici. Asian J. of Plant Pathol., 4(1): 34-42.

Lodha, S.; Mawar, R. and Singh, V. 2010. Non chemical options for managing soilborne plant pathogens in Indian arid zone. Acta Hort., 838:331-336.

Markus, D.K.; Mckinnon, J.P. and Buccaturi, A.F. 1982. Automated Analysis of Nitrate and ammonium Nitrogen in Soils. New Jersey Agric. Exp. Stn. Publications No. D15117.

Martin, J.P. 1950. Use of acid, rose Bengal and streptomycin in the plate method for estimating soil fungi. Soil Sci., 69:215-233.

Morsy, E.M. 2005. Role of growth promoting substances producing microorganisms on tomato plant and control of some root rot fungi. Ph.D. Thesis, Fac. Agric., Ain Shams Univ., Egypt.

Naware, L.S. 2008. Control of root-rot of green been with composted rice straw fortified with Trichoderma harzianum. Amer.-Eur. J. of Agric. and Environ. Sci., 3(3):370-379.

Ojahian, M.R. 2011. Potential of Trichoderma spp. and Talaromyces flavus for biological control of potato stem rot caused by Sclerotinia sclerotiorum. Phytoparasitica, 39(2): 185-193.

Olsen, S.R.; Colc, C.V.; Watanable, F.S. and Dean, L.A. 1954. Estimation of Available Phosphorus in Soils by Extraction with Sodium Bicarbonate. Vis. Dept. Agric., 939.

Omar, S.A.; Salem, D.E and El-Gantiry, S.M. 1994. Effect of some fungicides, sowing date, and seed rate on the incidence of root rot/wilt disease complex and yield of guar crop. Egypt. J. Agric. Res., 72(1): 59-69.

Page, A.L.; Miller, R.H. and Keeny, D.R. 1982. Methods of Soil Analysis. II: Chemical and microbiological properties. Soil Sciences America, Madison, Wisconsin, Volume 148, Issue 3, USA. https://doi.org/10. 1002/ jpln. $\underline{19851480319}$

Pane, C.; Vellecco, D.; Campanile, F. and Zoccardelli, M. 2012. Noval strains of Bacillus, isolated from compost and compost amended soils as biological

Egypt. J. Phytopathol., Vol. 46, No. 2 (2018) 
control agents against soil-borne phytopathogenic fungi. Biocont. Sci. and Technol., 22(12):1373-1388.

Piper, C.S. 1950. Soil and Plant Analytsis. $1^{\text {st }}$ Interscience Publishers Inc., New York, USA, 30-229.

Punja, Z.K. 1985. The biology, ecology and control of Sclerotium rolfsii. Ann. Rev. Phytopathol., 23:97-127.

Rivera, M.C.; Wright, E.R.; Lopes, M.V.; Garda, D. and Barraque, M.Y. 2004. Promotion of growth and control of damping-off ( $R$. solani) of greenhouse tomatoes amended with vermicompost. Phyton, 4(7):229-235.

Salem, W.M.; Sayed, W.F.; Abdel-Fattah, H. and Neamat, H.H. 2012. Assessment of compost for suppression of Fusarium oxysporum and improving Zea mays and Hibiscus sabdarriffa resistance to wilt diseases. Afr. J. of Biotechnol., 11(69): 13404-13414.

Shahiduzzaman, M.D. 2015. Efficacy of fungicides and botanicals in controlling foot and root rot of lentil. Bang. J. of Agric. Res., 40(4):711-715.

Singh, D.; Ram, H.; Sing, A.K., Maurya, B.R and Prasad, N.D. 2008. Influence of different nutrient sources on nodulation, growth and yield of chickpea. Indian J. of fert., 2:59-69.

Singh, R.; Soni, S.K. and Kalra, A. 2013. Synergy between Glomus fasciculatum and a beneficial Pseudomonus in reducing root diseases and improving yield and forskolin content in Coleus forskohlii Briq. under organic field conditions. Mycorrhiza, 23(1):35-44.

Singh, R.; Singh, R.; Soni, S.K.; Singh, S.P.; Chauhan, U.K. and Kalar, A. 2013. Vermicompost from biodegraded distillation waste improves soil properties and essential oil yield of Pogostemon cablin. Appl. Soil Ecol., 7048-7056.

Singh, V.; Mawar, R. and Lodha, S. 2012. Combined effects of biocontrol agents and soil amendments on soil microbial population, plant growth and incidence of charcoal rot of cowpea and wilt of cumin. Phytopathol. Medit., 51(2): 307316.

Skinner, F.A.; Jones, P.G. and Molison, J.E. 1952. A comparison between a direct and a plate counting technique for quantitative counts of soil microorganisms. J. Gen. Microbiol., 6: 261-271.

Vinale, F.; Flematt, G.; Sivasithamparam, K.; Lorito, M.; Marra, R.; Skelton, B.W. and Ghisalberti, E.L. 2009. Harzianic acid, an antifungal and plant growth promoting metabolite from Trichoderma harzianum. J. of Nat. Prod., 72(11): 2032-2035.

Egypt. J. Phytopathol., Vol. 46, No. 2 (2018) 
Xiaojia, H.; Minghari, Z.; Bing, Y.U.; Lihua, X.; Yugui, C.; Yinshui, L.; Shengyi, L. and Xing, L. 2010. Isolated fungal strains of inhibiting sclerotia germination and primarily study of biocontrol. Chinese J. of Oil Crop Sci., 32(4): 567-570.

Yanli, N.; Wang, L.I.; Yang, H.J. and Tong, Q. 2012. Inhibitory effect of compost as nursery substrates on root rot of Anthocephalus chinensis. J. of Northeast Fores. Univ., 40(10):103-107.

Zaghloul, R.A.; El-Husseiny, T.M.; Hanafy, E.A.; Rahal, A.G. and Abdel Rahman, H.M. 2010. Effect of biofertilization and organic manuring on soil dehydrogenase activity, macronutrients and essential oil of marjoram. Egypt. J. Microbiol., $13^{\text {th }}$ Conf. Microbiol., 15-32.

Zhang, S.; Reddy, M.S. and Kloepper, S.A. 2004. Tobacco growth enhancement and blue mold disease protection by rhizobateria: Relationship between plant growth promotion and systemic disease protection by PGPR strain-90-166. Plant and Soil, 262:277-288.

(Received 10/08/2018; in revised form 23/09/2018) 


\section{تأثير كمبوست الأرز المعزز بالميكروبات المضادة فى مقاومة عفن جذور الجوار

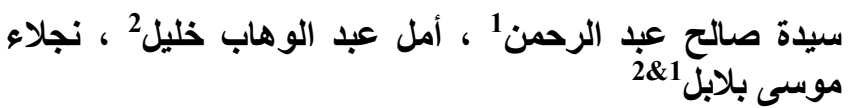

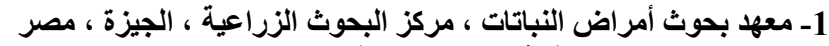

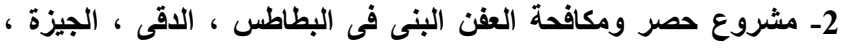

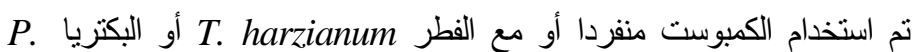

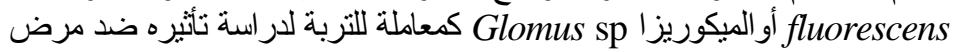
عفن الجذور فى نبات الجوار المتسبب عن الفطر Solfsii.

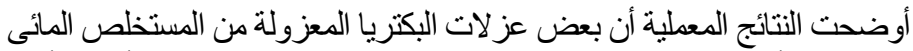

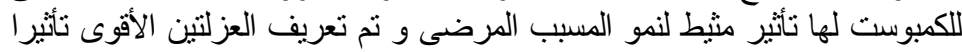

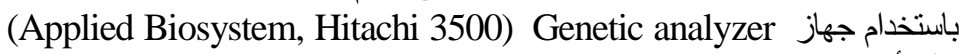
. B. amyloliquefaciens ، Bacillus subtilis : على أنخها

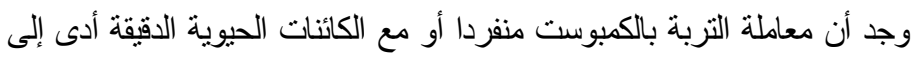

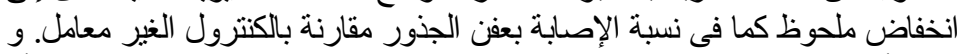

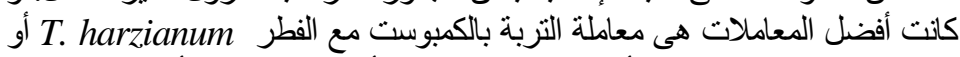

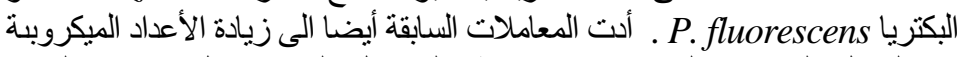

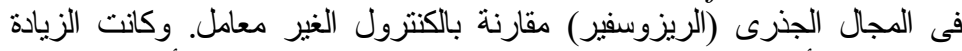

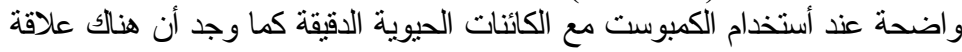
سليية بين نسبة حدوث الإصابة بالمرض والكات الاعداد الميكروبية فى المجال الجنرى (الريزوسفير).

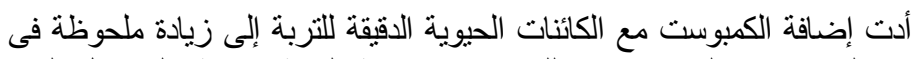

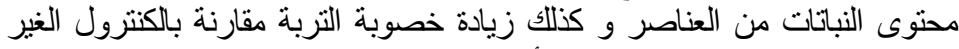

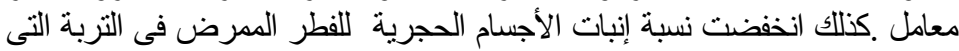

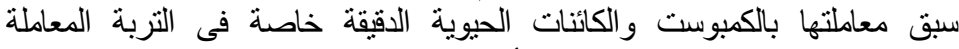

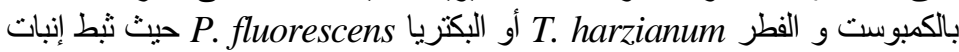

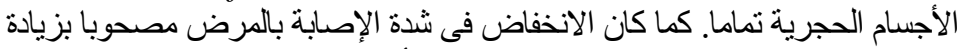
في الوزن الجاف و الرطب للنباتات المعاملة وأعداد العقد الجذرية للنباتات مقارئات الإنة

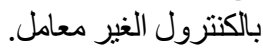

